\section{A CONTRIBUTION TO THE STUDY OF}

\section{PIPERAZINE.}

BY JOHN GORDON, M.D.,

Physician Aberdeen General Dispensary; Assistant to Professor of Materia Medica, University of Aberdeen.

THe following study was undertaken to ascertain the solvent action of piperazine on uric acid. Uric acid calculi were employed, as well as uric acid deposits in urine, and also artificially prepared uric acid. In contrast to other observers, who estimated the solvent action of piperazine on uric acid in the presence of water, the experiments to be described were all done in the presence of urine. It was supposed that investigations conducted in this way were more likely to yield results in accordance with the conditions that exist in the system when piperazine is exhibited to combine with the uric acid present in the blood, the urine, or retained in the form of calculi in the bladder. Piperazinum purum was the form in which the drug was used in all the experiments.

\section{Characters of Piperazing.}

Brown-Séquard in 1889 stated to the Paris Société de Biologie the result of various injections of extracts made from the testicles of young animals; amongst these were the sensations of enhanced well-being and increased nervous and muscular capability. Disagreeable symptoms of reaction at the injection points led to the solution of the active principle in the extracts, this active principle being termed spermine. Spermine is an organic base, its phosphate occurring in the form of crystals. Schreiner in 1878 obtained crystals from fresh seminal fluid, also from calves' livers, the formula of which was $\mathrm{C}_{2} \mathrm{H}_{5} \mathrm{~N}$. Ladenburg and Abel, by the action of heat on hydrochlorate of ethylenediamine, obtained a base which which they called ethylenimine $\left(\mathrm{C}_{2} \mathrm{H}_{4} \mathrm{NH}\right)$, and this they regarded as the same as Schreiner's crystals. Kobert investigated this base ethylenimine physiologically, and found that it was non-poisonous.

The formula of piperazine is $\mathrm{C}_{1} \mathrm{H}_{10} \mathrm{~N}_{2}$, or two molecules of spermine $\left(\mathrm{C}_{2} \mathrm{H}_{5} \mathrm{~N}\right)$. It is also called dispermine. In graphic formula it may be thus represented :

$$
\mathrm{CH}_{\mathrm{NH}}^{\mathrm{CH}_{2}} \overbrace{\mathrm{CH}_{2}}^{\mathrm{NH}}
$$

It is a piperidin in which one $\mathrm{CH}_{2}$ group is replaced by an imide or NH group. It is a synthetical compound, and was prepared to replace the active principle, spermine, which was obtained from testicular fluid. It has, however, been found to be a new body, both in its chemical and its physiological characters. It is manufactured by a patented process from the hydrochlorate of ethylenediamine, or from the acid derrivatives of ethylenediamine, by the action of sodium glycol : $\mathrm{C}_{2} \mathrm{H}_{4}(\mathrm{O} \mathrm{Na}) 2+\mathrm{C}_{2} \mathrm{H}_{4}\left(\mathrm{~N} \mathrm{HCO} \mathrm{R}^{1}\right) 2=$

$$
\left(\mathrm{C}_{2} \mathrm{H}_{4} \mathrm{~N} \mathrm{H}\right) 2+2 \mathrm{R}^{1} \mathrm{COO} \mathrm{Na}^{4}
$$

This is the method alleged to be employed by the Schering Company.

It may also be formed, in small quantities, by the reaction of glycol-ethylene alcohol $\left(\mathrm{C}_{2} \mathrm{H}_{4}(\mathrm{OH})\right)_{2}$ on ethylenediamine. Elimination of water takes place in this process, and only by the aid of high temperatures and dehydrating agents can a small quantity be procured.

$$
\begin{aligned}
& \mathrm{C}_{2} \mathrm{H}_{4}(\mathrm{OH}) 2+\mathrm{C}_{2} \mathrm{H}_{4}\left(\mathrm{NH}_{2}\right) 2= \\
& \left.\mathrm{C}_{2} \mathrm{H}_{4} \mathrm{NH}\right) 2+2 \mathrm{H}_{2} \mathrm{O} \\
& \text { piperazine water. }
\end{aligned}
$$

Physical and Chemical Properties.

Piperazine occurs in crystalline masses, sometimes acicular, at other times in lustrous tables. It is deliquescent, absorbing water and carbonic acid when exposed. It is readily soluble in water, and the solution is strongly alkaline. Its taste is cool, saline, or slightly ammoniacal, and bitter. It has a faint ammoniacal odour. Piperazine is soluble in normal urine, forming at first a clear solution. After a few seconds a flocculent precipitate (phosphates) begins to form ; the solution in urine is strongly alkaline.

In the system piperazine is not entirely oxidised, because it can be detected in the urine by the application of potassium bismuth-iodide. This test was employed frequently. One patient, to whom 2 grammes daily were given, may be selected as a type. The urine excreted was tested by the following method :

Ten c.c. of the urine were decomposed by a small quantity of concentrated solution of soda, and warmed for a short time. The solution was then filtered from the phosphates, which appear as a flocculent precipitate. Hydrochloric acid was then added in slight excess. Next potassium bismuth-iodide. A precipitate of nucleo-albumin forms; when the solution is lieated, this precipitate aggregates, and is got rid of by fitretion. The filtrate is then briskly stirred with a glass rod, and, after standing for a few hours, a compound of piperazine with bismuth fahs
out in purple red points, which tend to collect into groups of feathery out in purp

A control observation was made with urine, to which a definite quantity of piperazine was added. The application of the above test yielded crystals of like characters; and, calculating by the weight of the piperazine-bismuth compound obtained in this manner, it was estimated that the patient who took 2 grammes daily excreted unoxidised piperazine to the extent of 0.3 gramme.

The urine of the patient was slightly acid. No unpleasant. sensation has been complained of by any patient. In none has there been evidence of gastric disturbance nor loss of appetite. In all cases the drug was given well diluted in water. It is proposed in a future paper to detail clinical observations on the drug.

\section{Action of Piperazing on Uric acid Calcela.}

The calculi employed in these experiments were not entirely composed of uric acid, but contained, in varying proportions, the other ingredients that form calculi. Uric acid was, however, the main ingredient. In each series of experiments the fragments employed were selected from the same calculus, as far as possible of the same size and shape, so that equal surfaces might be exposed to the various fluids.

Normal urine was the medium used in all the experiments, and the piperazine was contrasted in its solvent power with several other eubstances supposed to have the property of dissolving uric acid calculi. These other bodies were borax, sodium carbonate, lithium citrate, and potassium. citrate.

Method Employed.-The experiments were made by placing 10 c.e. of normal urine in test tubes in which had been dissolved a percentage of the solvent substances. A piece of uric acid calculi weighing $50 \mathrm{mg}$. the solvent substances. A piece of uric acid calculi weighing 50 mg. or $100 \mathrm{mg}$. Was then added to each test tube. The test tubes were then transferred to a water bath, which was kept at $39^{\circ} \mathrm{C}$. At definite times the whole of the test tubes were shaken for an equal period of time, and at fixed intervals the fragments, after careful drying on filtering paper by cotton wool during the whole of the experiments to prevent decomposition of the urine.

The simple solubility of uric acid in water by the agency of the various solvents is quite a distinct condition from their solubilities in urine in the presence of the products of tissue activities and changes. It is also to be remembered that still other results regarding solubility with the various substances employed may be obtained if the urine be pathological in its character.

The accompanying tables and charts illustrate the results in the various series of experiments on the solubility of uric acid calculi.

To ascertain what relation the strength of the solution of piperazine had to the rate of solubility further sets of experiments were initiated; and the following may serve as an example :

Fragents of a uric acid calculns of equal size, shape, and weight were Fragments of a uric acid calculus of equal size, shape, and weight were taken, and treated in the manner before mentioned. The strengths of the solutions of piperazine in urine were 5 per cent., 2.5 per cent., and 1.25 per cent. The results at the end of twelve hours were: The 5 per cent. solution had reduced the weight 12 per cent.; the 2.5 per cent.; per cent.; the 1.25 per cent., 8 per cent. The 5 per cent. solution had in addion rouction of other two solutions had also conitty in its character.

The result of this set of experiments was to indicate that the stronger solutions of piperazine had the greater solvent power; but that the difference was much less than might be expected from the relative strength of the solutions. This is a point of clinical importance, since it is proved that the piperazine is not entirely oxidised in the body, but that a 
Exprament I.-Comsisted in treating il) my. of Uric Acid Calculus in 10 c.c. of Normal Vrine, which contained 1 Per. Cent. of the following Substances. Tomperature $39^{\circ} \mathrm{C}$.

\begin{tabular}{|c|c|c|c|c|c|}
\hline 递 & Piperazinum Purum. & Berax. & Lithium ('itrate. & Sodium Carbonate. & Potassium Citrate. \\
\hline 15 & $\begin{array}{l}\text { Solution alkaline turbid; calculus } \\
\text { friable; loss in weight } 25 \mathrm{mg} \text {. }\end{array}$ & $\begin{array}{l}\text { Solution neutral; calculus } \\
\text { with white deposit; loss } \\
\text { in weight } 10 \text { mg. }\end{array}$ & $\begin{array}{l}\text { Solution faintly acid; cal- } \\
\text { culus no change; no loss } \\
\text { of weight }\end{array}$ & $\begin{array}{l}\text { Solution alkaline; slight } \\
\text { deposit in calculus; no } \\
\text { loss in weight }\end{array}$ & $\begin{array}{l}\text { Solution neutral; calculus } \\
\text { unchanged; no loss in } \\
\text { weiglit. }\end{array}$ \\
\hline 27 & $\begin{array}{l}\text { Solution same as above; calculus: } \\
\text { disintegrating; loss in weiglt } 30 \\
\text { mg. }\end{array}$ & $\begin{array}{l}\text { Solution neutra; calculus } \\
\text { with white deposit; loss } \\
\text { in weight } 20 \mathrm{mg} \text {. }\end{array}$ & $\begin{array}{l}\text { Solution neutral ; no evi- } \\
\text { dent change in calculus } \\
\text { loss in weight } 5 \text { mg. }\end{array}$ & $\begin{array}{l}\text { Solution as above; calculus } \\
\text { with deposit; ; loss in } \\
\text { weight } 5 \text { mg. }\end{array}$ & No change. \\
\hline 37 & $\begin{array}{l}\text { Solution as above; calculus very } \\
\text { friable; loss in weight still } 30 \mathrm{mg}\end{array}$ & $\begin{array}{l}\text { solution turbid ; white de- } \\
\text { posit in calculus; no fur- } \\
\text { ther loss in weight. }\end{array}$ & $\begin{array}{l}\text { Solution neutral; no change } \\
\text { in calculus; no further } \\
\text { loss in weiglit }\end{array}$ & $\begin{array}{l}\text { Solution as above; calculus } \\
\text { with deposits; no further } \\
\text { loss in weight }\end{array}$ & No change. \\
\hline 47 & $\begin{array}{l}\text { Solution as above; calculus very } \\
\text { soft, friable; loss in weight } 40 \mathrm{mg} \text {. }\end{array}$ & $\begin{array}{l}\text { Solution as above; calcu- } \\
\text { lus as above; no further } \\
\text { loss in weight }\end{array}$ & $\begin{array}{l}\text { Solution as above ; no } \\
\text { change in calculus; loss } \\
\text { in weight } 10 \mathrm{mg} \text {. }\end{array}$ & $\begin{array}{l}\text { Solutioul as above; calculus } \\
\text { as above; loss in weight } \\
10 \mathrm{mg} \text {. }\end{array}$ & Loss in weight $4 \mathrm{mg}$. \\
\hline 71 & $\begin{array}{l}\text { Solution as above; calculus pulpy; } \\
\text { loss in weight } 46 \mathrm{mg} \text {. }\end{array}$ & No further change & No further change & No further change & No further change. \\
\hline & Total loss in weight $46 \mathrm{mg}$ & Total loss in weight $20 \mathrm{mg}$. & Total loss in weight $10 \mathrm{mg}$. & otal loss in weight $10 \mathrm{mg}$. & Total loss in weight $4 \mathrm{mg}$. \\
\hline
\end{tabular}

The activity of the urine containing the piperazine continued till 11 hours had elapsed, when the calculus was practically dissolved. No further solivent action was obtained after 47 hours by any of the other bodies. The percentage solution in 71 hour's was 92 per cent. for piperazine, 60 per cent. borax, 20 per cent. lithium citrate, 20 per cent. sodium carbonate, 8 per cent. potassium citrate.

Expermant II.-Consisted in treating $50 \mathrm{mg}$. of Uric Acid Calculus in 10 c.c. of Normal Urine which contained 2 Per Cent. of tho undermentioned Substances. Temperature $39^{\circ} \mathrm{C}$.

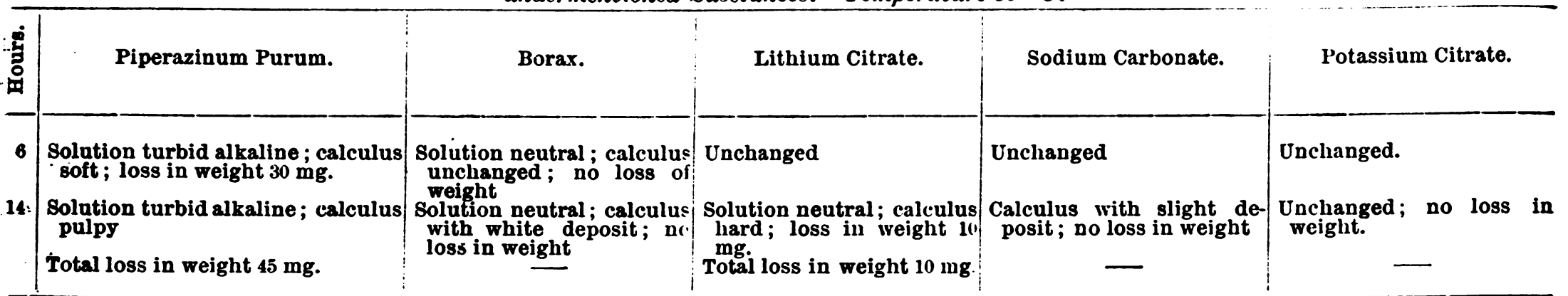

Expeniment III.-100 mg. of Uric Acid Calculus vere Digested at $39^{\circ} \mathrm{C}$. in 5 Per Cent. Solutions of the undermentioned Substances in Normal Urine.

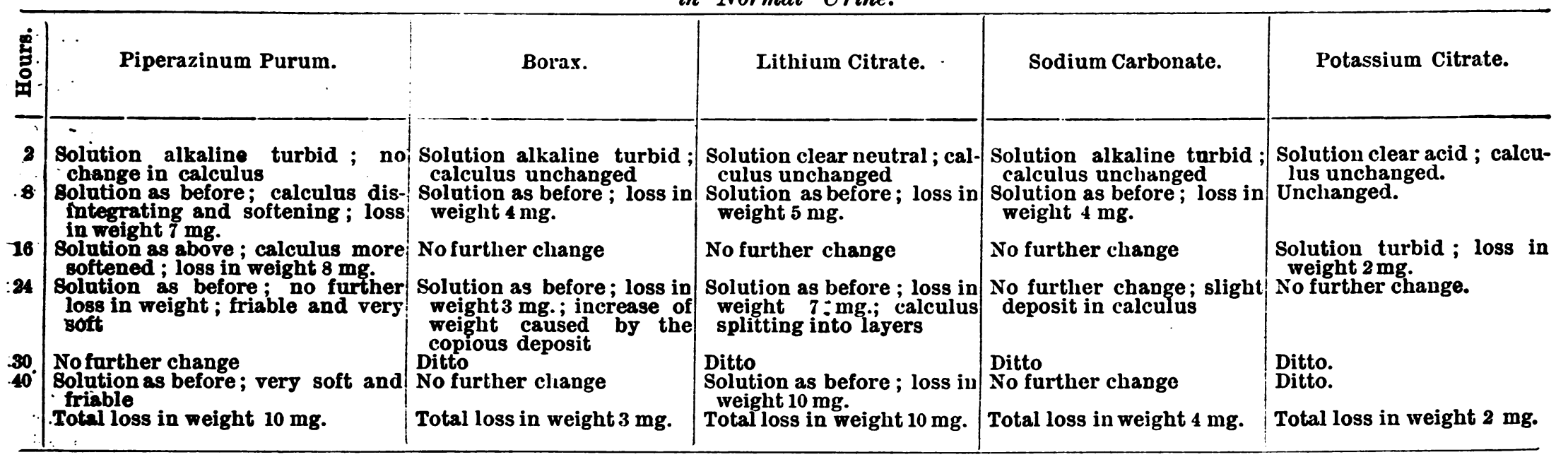

Exprangers IV.-100 mg. of Uric Acid Calculus were Digested at $39^{\circ} \mathrm{C}$. in 7.5 Per Cent. Solvtions of the following Substances in Normal Urine.

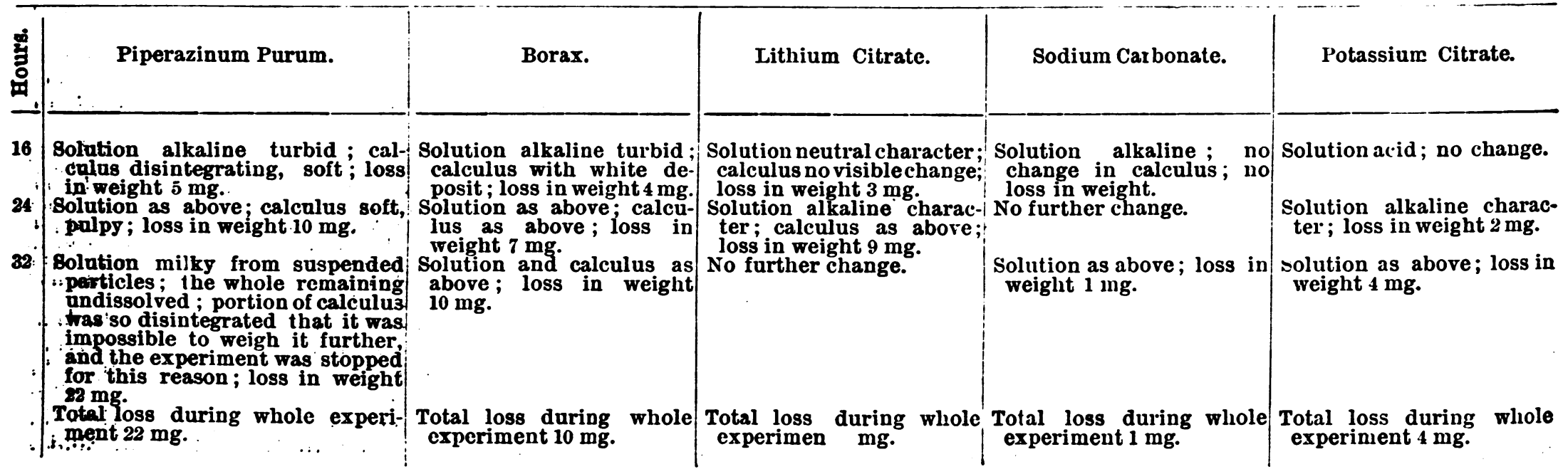


considerable amount is excreted unchanged and in a state to combine with uric acid in excess.

The deduction from these various experiments with difThe strengths of piperazine on uric acid calculi is that it has a distinct power of dissolving 80 far the calculi, that the parts of the calculi that remain undissolved are rendered soft and friable, and that frequently the fragments of calculi are disintegrated into a granular pulp.

Experiments with solutions weaker than 1 per cent. were not undertaken. It was, however, evident that with solutions of 1 per cent. a very considerable solvent action was obtained on calculi, provided these experiments were continued over a fairly long period. With solutions of 2 per cent. more lactivity was indicated in solvent power, as is shown in the experiment detailed, and the time at which action took place was earlier. In this experiment there was a loss of weight of $30 \mathrm{mg}$. in six hours, and at the end of fourteen hours the loss had increased to $45 \mathrm{mg}$., the remaining undissolved portion of the fragment of calculus having become quite pulpy.

It may therefore be stated that, as the result of the whole ceries of experiments, piperazine is a substance which, in strengths of 1 per cent. to 7.5 per cent. in normal urine, at the temperature of $39^{\circ} \mathrm{C}$., has the property of dissolving uric acid calculi, and of disintegrating and rendering soft and pulpy the undissolved portion.

So soft often are the undissolved portions of the calculi which have been exposed to the action of the piperazine solutions, that it may be possible that the normal movements of the tissues in the parts where the calculus may be lodged might in some cases succeed in completing the action which the piperazine has initiated, and lead to the expulsion of the pulpy débris.

Borax and Lithiux Citrate.

The other substances that contrast favourably with piperazine are borax and lithium citrate. With both of these substances there was always obtained, after a longer or shorter time, a loss in weight of the calculus, never so great as that with the piperazine experiment. And with none of the other substances was there any evidence of softening in the fragment, the calculus at the end of the contact with the solutions being as hard as it was at the beginning. With the borax solutions there was, especially with the stronger ones, an abundant white deposit on the fragments. In one case, namely, that with 5 per cent. of the lithium citrate there was evidence that the calculus was splitting into its original concentric layers, but no softening had taken place.

Sodium carbonate and potassum citrate showed but little activity as solvents of uric acid calculi in fragments.

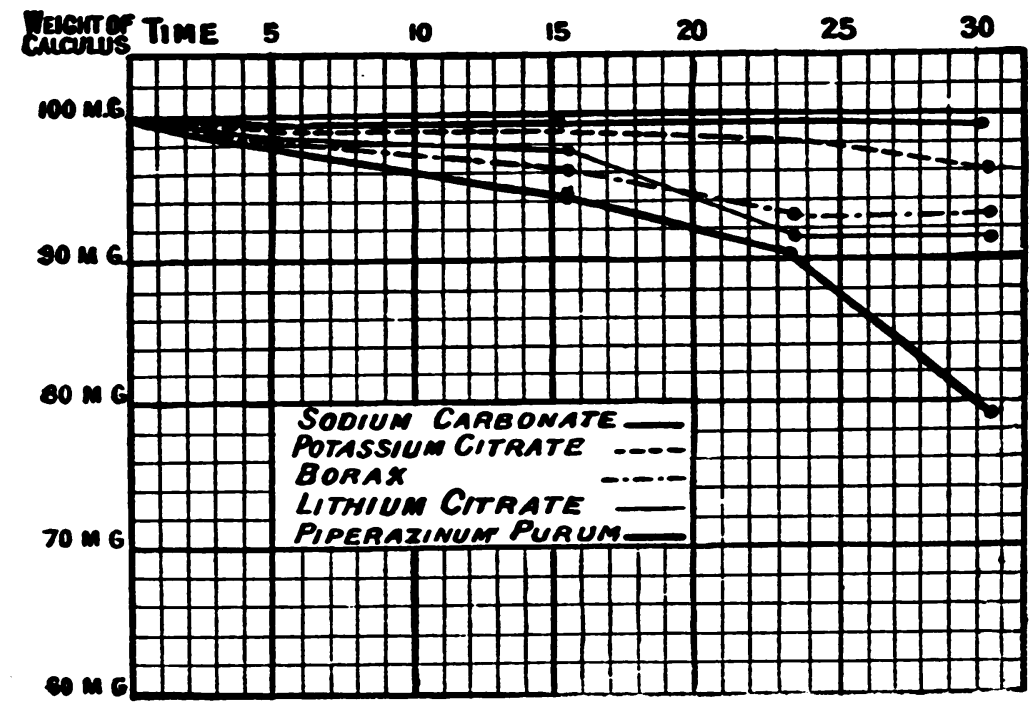

Sodium Carbonate - In an experiment with 1 per cent. the solvent action heran betrween the thinteenth and serenteenth hour, at which latter hour con a loss of $\mathrm{mg}$. was found to have taken place, no further loss in weight took place till the forty-seventh hour, when there was $10 \mathrm{mg}$. of loss the fragment then till the seventy-first hour remained unchanged in weight. With a 2 per cent. solution of the sodium carbonate no alteration in weight took place in fourteen hours. After the action of a 5 pe cent. solution for eight hours, $100 \mathrm{mg}$. of a uric acid calculus los 4 mg., and though the fragment was exposed till the end of fort.y lours no further loss was sustained. Another fragment of $100 \mathrm{mg}$. on

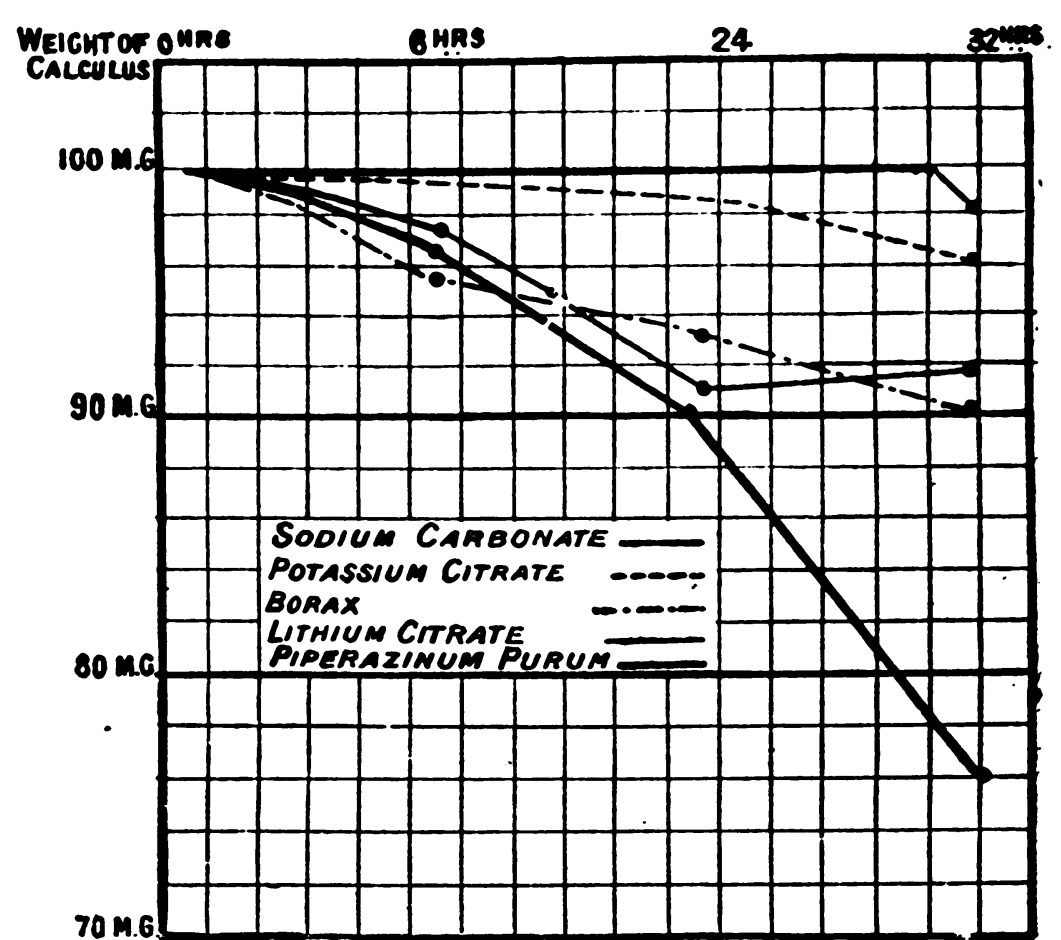

Potassium Citrate.-After exposure of forty-seven hours to a 1 per cent. solution there was a loss of $4 \mathrm{mg}$. in a fragment which weighed $50 \mathrm{mg}$.; and fourteen hours' exposure to a 2 per cent. solution effected no alteration in weight; while the action by a 5 per cent. solution for sixteen hours dissolved only $2 \mathrm{mg}$. of a calculus that weighed $100 \mathrm{mg}$. Further a solution of 7.5 per cent. in twenty-four hours reduced a fragment

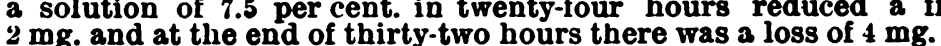

\section{Experiments with Calcoli of Ascertajned} Composition.

It was thought that more exact results might be obtained if calculi of known composition were employed to test the solvent activity of the various substances that were employed in these series of experiments. I have to thank $\mathbf{M r}$. T. $\mathbf{S}$. Murray, D.Sc., assistant to the Professor of Chemistry in the University of Aberdeen, for his kindness in analysing the calculi. The one, the results of which are appended in the accompanying table and chart, had the following composition.

Uric, phosphoric, and sulphuric acids, along with magnesia and lime, were estimated in one portion of the powdered calculus. Water was determined by heating another portion to $110^{\circ} \mathrm{C}$., and volatile and oxidisable organic matter was determined in the same portion by heating repeatedly organic matter was determined in thally igniting. The loss on heating with concentrated nitric acid, and finally igniting. Th.

The analytical results are as follows:

$$
\begin{aligned}
& \text { I oss on ling to } 110^{\circ} \mathrm{C} \text {., water } \\
& \text { " " igniting } \\
& \text { Consisting of }\left\{\begin{array}{l}
\text { Uric acid } \ldots \text { Other organic matter and ammonia } \\
\text { Öm }
\end{array}\right. \\
& \left\{\begin{array}{lll}
\text { by difference } \ldots & \ldots & =19.08
\end{array}\right. \\
& \text { Phosphoric anhydride } \mathrm{P}_{2} \mathrm{O}_{3} \quad \ldots \quad \text {... }
\end{aligned}
$$

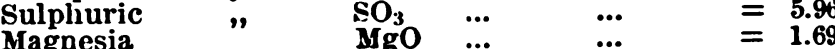

$$
\begin{aligned}
& \begin{array}{lllll}
\text { Magnesia } & \text { MgO } & \ldots & \ldots & =1.69 \\
\text { Lime } & \text { CaO } & \ldots & \ldots & =
\end{array}
\end{aligned}
$$

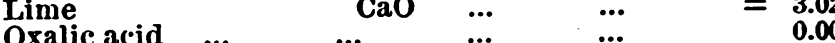

$$
\begin{aligned}
& 99.12
\end{aligned}
$$

In this set of experiments the calculus was employed in the form of a fine powder, which was added to the test tube which contained the 10 c.c. of urine to which had been added the 1 per cent. of the solvent agent. In order to get rid of the phosphates in urine, it was first treated witn a slight excess of ammonium hydrate, and the precipitate removed by filtration.

The result of these experiments was to show that in twenty-four hours a 1 per cent. solution of piperazine was capabie of dissolving $48 \mathrm{mg}$. of the $50 \mathrm{mg}$. employed. In the earlier stages of the experiment it was plod. that borax had a solvent action as marked as the piperazine, but that this potency in solution was sooner expausted in the borax, and that after eighteen hours the solution of borax had no further action. It will also be observed that in these experiments all the other substances evinced greater solvent power than when the calculus was employed in 
the form of fragments, no doubt owing to the fact that greater surface was offered to their activity. Not only was the piperazine solution capable of dissolving the uric acid contained in the calculus, but it also dissolved nearly the whole of the other ingredients that were present, for out of the $50 \mathrm{mg}$. employed only $2 \mathrm{mg}$. were left undissolved.

TABLE IV.-E.eperiment to show the Action of 1 per cent. Solution of Piperazine in Normal Urine on 50 Milligrammes of a C'alculus, the Composition of which had been ascertained by Analysis. Temperature $39^{\circ} \mathrm{C}$.

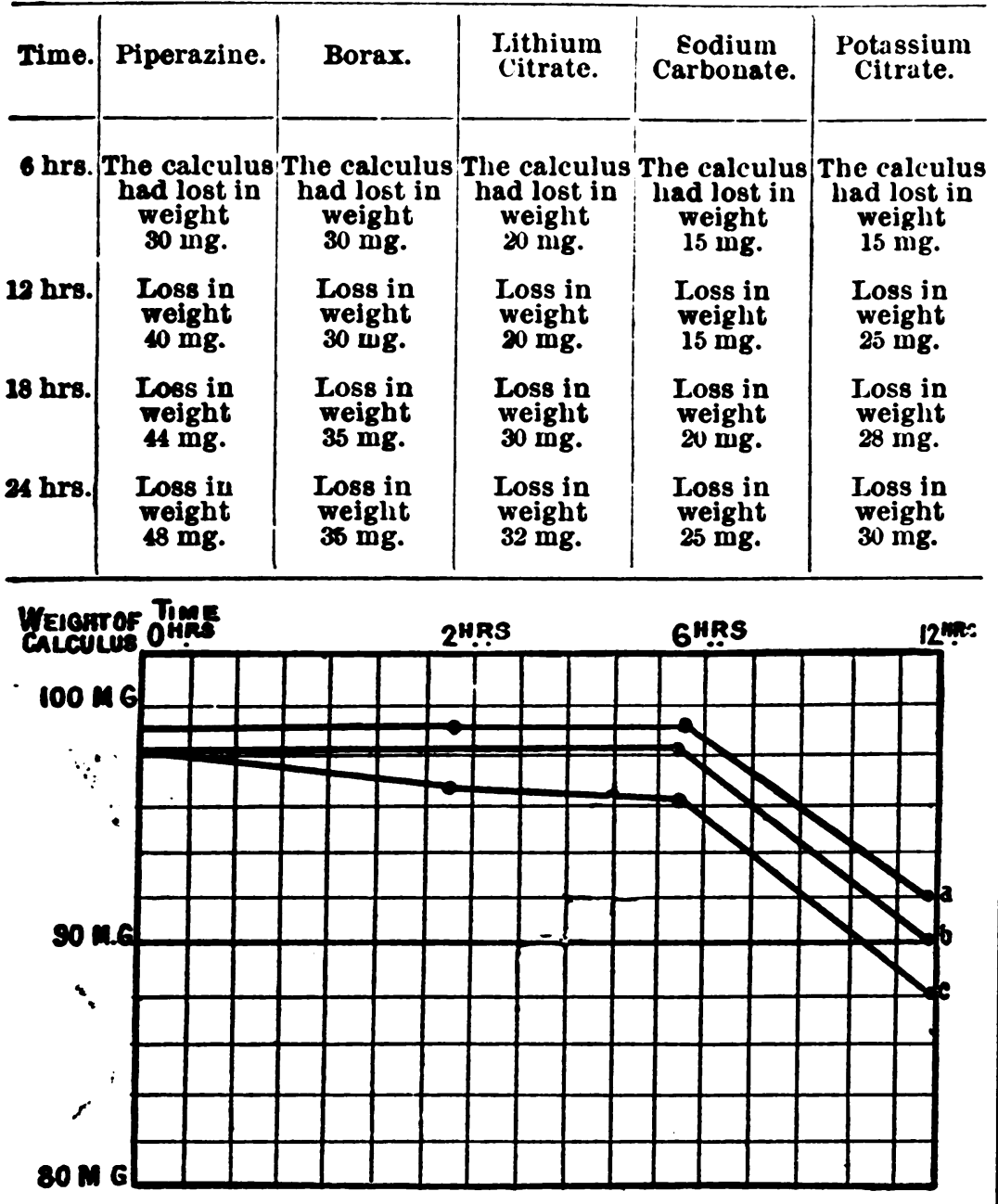

Action of Piperazing on artificial Uric Acid.

As the result of numerous experiments on artificial uric acid, and also on uric acid which was collected from urine which had been treated with hydrochloric acid, it was found that piperazine was capable of dissolving almost its own weight in urine, after the phosphates had been removed; but when stronger solutions than 2.5 per cent. were employed an insoluble precipitate formed.

\section{SUMmary OF Results.}

1. Piperazine is not wholly oxidised in the body, and may be detected in the urine of those to whom it is exhibited.

2. Piperazine in solutions of 1 per cent. in normal urine, when kept in contact at a temperature of $39^{\circ} \mathrm{C}$. (body temperature) for a given time, has the property of dissolving to a great extent a fragment of a uric acid calculus.

3. That the stronger the solution of piperazine in urine (up to 7.5 per cent.) the earlier did the solvent action begin and the more rapid was the completion.

4. That, notwithstanding this, with the stronger solutions of piperazine in urine the rate of solubility was not so markedly rapid over the weaker solutions as might be expected.

5. That the solvent action of piperazine in similar circumstances was greater than any other of the substances that were employed, namely, borax, lithium citrate, sodium carbonate, and potassium citrate.

6. That piperazine, in weak and strong solutions in urine, converted the undissolved portion of the calculus into a soft granular or pulpy condition.
7. That neither borax, lithium citrate, sodium carbonate, nor potassium citrate in similar circumstances rendered the fragment of calculus soft or pulpy.

In conclusion, my thanks are due to Professor John Theodore Cash, F.R.S., in whose pharmacological laboratory the experiments were for the most part performed, for his guidance and suggestion. I have to express my obligations to Professor Alexander Ogston, to whom I was indebted for supplies of calculi, which he most willingly placed at my disposal. I have also to acknowledge that the expenses connected with these investigations were defrayed by the Scientific Grants Committee of the British Medical Association.

\section{EIGHT HUNDRED AND FIFTY-TWO OPERATIONS FOR STONE IN THE BLADDER. ${ }^{1}$}

By P. J. FREYER, M.A., M.D., M.CH., Surgeon-Major H.M. Bengal Army.

Mr first lithotomy operation was performed on May 4th, 1877. Since that time I have operated on 852 cases of stone in the bladder by all methods-namely, 245 by perineal lithotomy, 6 by suprapubic lithotomy, 3 by rapid dilatation of the urethra in females, and 598 by litholapaxy, or "lithotrity at one sitting," as the operation is sometimes called. Though for statistical purposes it will be necessary for me to deal comprehensively with the whole of my operations for stone, it is to these latter 598 cases removed by Bigelow's method that I propose directing particular attention in the present paper-demonstrating what a vast influence the modern operation has had in ameliorating the sufferings and diminishing the mortality attendant on stone in the bladder.

I performed my first litholapaxy operation on July 3rd, 1882. In 1886 I published my work on litholapaxy, ${ }^{2}$ dealing with 128 cases of the operation performed by me down to the beginning of that year. I have from time to time published papers in the medical journals (BRITIsH Medical JodRnal, Lancet, Indian Medical Gazette) giving full details of several series of this operation performed by me. The great majority of these operations were done in hospital practice, and careful notes of every case have been kept by my assistant surgeons and myself. In a large proportion $I$ have had the pleasure of operating in the presence of one or more surgeons and showing them the results. There was no selection of cases, my rule being to operate on every patient suffering from stone coming under my care, no matter in what condition. No case was allowed to leave hospital, or observation in case of private practice, till a cure had been effected. My paper may, therefore, be accepted as an accurate and trustworthy record of work in this branch of surgery.

$A$ word in the first place about the instruments now used by me in this operation. The lithotrites are all of one pattern, (Fig. 1) having fully fenestrated blades, with Bigelow's handle and mechanism for locking and unlocking the blades. They range in size from $5 \frac{1}{2}$ to 18 (English) at the angle, the former being the smallest used for children and the litter the largest for adults. I have now abandoned the use of all but fullyfenestrated lithotrites in my practice. I consider the use of any other kind unnecessary, and almost unjustifiable, considering the danger that exists of debris getting impacted in the jaws of non-fenestrated instruments-an accident which cannot occur with fully fenestrated ones when properly used. The use of the lithotrite in the modern operation is to crush, never to fish out, the fragments-a rôle to which it was frequently consigned in the old operation of lithotrity. I cannot conceive any circumstances in which it would be advisable to use a non-fenestrated lithotrite in the modern operation. After having used many forms of aspirator, I have now abandoned all others in favour of Bigelow's simplified aspirator (Fig. 2), modified by Weiss of London, in accordance with suggestions made by myself and others. The cannulæ (Fig.3) used by me are only slightly curved, with the eye on the concave surface close to the end. These are more easily introduced into the bladder, and more effective than straight

Read at the International Medical Congress held in Rome, April, 1894 The Modern Treatment of Stone in the Bladder by Litholopaxy. Iondon: J. and A. Churchill. 